\title{
Cow and environmental factors associated with protein fractions and free amino acids predicted using mid-infrared spectroscopy in bovine milk
}

\author{
A. McDermott, ${ }^{*} \dagger$ M. De Marchi, $\dagger$ D. P. Berry, ${ }^{*}$ G. Visentin, ${ }^{\star} \dagger$ M. A. Fenelon, $\ddagger$ N. Lopez-Villalobos,, \\ and S. McParland*1 \\ ${ }^{*}$ Teagasc Animal and Grassland Research and Innovation Centre, Moorepark, Fermoy, Co. Cork, Ireland \\ †Department of Agronomy, Food, Natural Resources, Animals and Environment (DAFNAE), University of Padova, Viale dell'Universita 16, \\ 35020 Legnaro (PD), Italy \\ $\ddagger$ Teagasc, Food Research Centre, Moorepark, Fermoy, Co. Cork, Ireland \\ §Institute of Veterinary, Animal and Biomedical Sciences, Massey University, Private Bag 11222, Palmerston North 4442, New Zealand
}

\begin{abstract}
The objective of the present study was to identify the factors associated with both the protein composition and free amino acid (FAA) composition of bovine milk predicted using mid-infrared spectroscopy. Milk samples were available from 7 research herds and 69 commercial herds. The spectral data from the research herds comprised 94,286 separate morning and evening milk samples; the spectral data from the commercial herds comprised 40,260 milk samples representing a composite sample of both the morning and evening milkings. Mid-infrared spectroscopy prediction models developed in a previous study were applied to all spectra. Factors associated with the predicted protein and FAA composition were quantified using linear mixed models. Factors considered in the model included the fixed effects of calendar month of the test, milking time (i.e., morning, evening, or both combined), parity (1, $2,3,4,5$, and $\geq 6$ ), stage of lactation, the interaction between parity and stage of lactation, breed proportion of the cow (Friesian, Jersey, Norwegian Red, Montbéliarde, and other), and both the general heterosis and recombination coefficients of the cow. Contemporary group as well as both within- and across-lactation permanent environmental effects were included in all models as random effects. Total proteins (i.e., total casein, CN; total whey; and total $\beta$-lactoglobulin) and protein fractions (with the exception of $\alpha$-lactalbumin) decreased postcalving until 36 to 65 days in milk and increased thereafter. After adjusting the statistical model for differences in crude protein content and milk yield separately, irrespective of stage of lactation, younger animals produced more total proteins (i.e., total CN, total whey, and total $\beta$-lactoglobulin) as well as more total FAA, Glu, and Asp than their older con-
\end{abstract}

Received December 6, 2016.

Accepted April 21, 2017.

${ }^{1}$ Corresponding author: sinead.mcparland@teagasc.ie temporaries. The concentration of all protein fractions (except $\beta-\mathrm{CN}$ ) in milk was greatest in the evening milk, even after adjusting for differences in the crude protein content of the milk. Relative to a purebred Holstein cow, Jersey cows, on average, produced a greater concentration of all CN fractions but less total FAA, Glu, Gly, Asp, and Val in milk. Relative to their respective purebred parental average, first-cross cows produced more total CN and more $\beta-\mathrm{CN}$. Results from the present study indicate that many cow-level factors, as well as other factors, are associated with protein composition and FAA composition of bovine milk.

Key words: mid-infrared spectroscopy, protein composition, free amino acid composition

\section{INTRODUCTION}

Total protein content and its composition in bovine milk are among the most important milk characteristics for the dairy industry. In Europe, milk processors pay a greater premium for milk exceeding a threshold protein content than for milk exceeding a threshold fat content (Shalloo and Geary, 2011). Bovine milk generally consists of approximately $3.3 \% \mathrm{CP}$, of which $78 \%$ is $\mathrm{CN}, 17$ to $18 \%$ is whey protein, and the remaining 4 to $5 \%$ is NPN (predominantly urea; DePeters and Ferguson, 1992). Milk CN consists of $4 \mathrm{CN}$ fractions $\left(\alpha_{\mathrm{S}^{-}} \mathrm{CN}, \alpha_{\mathrm{S}^{-}} \mathrm{CN}, \beta-\mathrm{CN}\right.$, and $\left.\kappa-\mathrm{CN}\right)$ in the approximate proportion of 3:1:3:1 (Farrell et al., 2004) and $\gamma$-CN, which is a product of degradation of $\beta-\mathrm{CN}$ (Miller et al., 1990; Ostersen et al., 1997). Changes in the concentration of individual protein fractions in milk affect various processing attributes of the milk, including rennet coagulating time (Ikonen et al., 2004; Joudu et al., 2008), curd firmness (Ikonen et al., 2004; Wedholm et al., 2006; Joudu et al., 2008), pH (Ikonen et al., 2004; Joudu et al., 2008), and cheese yield (Wedholm et al., 2006; Bonfatti et al., 2011).

Results from numerous studies reveal that parity, stage of lactation (Kroeker et al., 1985; Ng-Kwai-Hang 
et al., 1987; Ostersen et al., 1997), and breed (Auldist et al., 2004; Joudu et al., 2008; Lopez-Villalobos, 2012) are associated with the individual protein fractions of milk. For example, mean $\alpha_{S}-\mathrm{CN}$ was reported to increase between first- and third-parity cows but plateaued thereafter, whereas $\beta$-CN decreased as parity number increased (Kroeker et al., 1985; Ng-Kwai-Hang et al., 1987). Changes in the proportions of $\alpha_{S_{1}}-\mathrm{CN}$, $\beta-\mathrm{CN}$, and $\kappa-\mathrm{CN}$ in milk have also been associated with stage of lactation and cow parity (Kroeker et al., 1985).

Free AA (FAA) in milk may be used as human nutritional supplements because they are more digestible than protein (Mero, 1999; Gleeson, 2008). For milk processing purposes, a high level of FAA is undesirable because FAA are a result of deproteinization and an indication of poorer milk quality. Therefore, bovine milk is less suitable for processing in early and late lactation, when total FAA are in greatest concentration (Auldist et al., 1995; McDermott et al., 2016a). Nevertheless, to date, no study has investigated the variability in FAA across different parities, milking time of the day, month of the year, or dairy breeds.

Mid-infrared spectroscopy (MIRS) is commonly used worldwide to predict milk fat, protein, CN, and lactose of individual animal and bulk tank milk samples. Previous studies propose MIRS as a rapid and cost-effective analytic tool for recording phenotypes at the population level (De Marchi et al., 2014; McParland and Berry, 2016). The ability of MIRS to predict milk technological traits, detailed protein composition $\left(\alpha_{\mathrm{S} 1}-\mathrm{CN}, \beta-\mathrm{CN}, \kappa-\mathrm{CN}, \alpha-\mathrm{LA}, \beta-\mathrm{LG} \mathrm{A}\right.$, and $\left.\beta-\mathrm{LG} \mathrm{B}\right)$, FAA, and milk color characteristics has been previously documented (McDermott et al., 2016a,b). The objective of the present study was to quantify the associations between cow-level factors, as well as other factors, with detailed protein and FAA composition of bovine milk predicted using MIRS.

\section{MATERIALS AND METHODS}

\section{Spectral Data}

Milk samples were available from 2 sources: 7 research herds operated by the Animal and Grassland Research and Innovation Center (Teagasc, Moorepark, Fermoy, Co. Cork, Ireland) and 69 Irish commercial dairy herds. Spectra from the research herds comprised 126,845 separate morning and evening milk samples from 2,535 lactations and 1,439 cows. Spectra from the commercial herds comprised 44,976 milk samples (morning and evening milk samples combined) from 14,874 lactations and 8,733 cows. Milk samples were from 2 seasonal calving systems (spring and autumn). Milk chemical composition (milk fat, protein, $\mathrm{CN}$, and lactose con- centration) was predicted for all milk samples using the same Fourier transform infrared spectrometer (Foss MilkoScan FT6000; Foss Electronic A/S, Hillerød, Denmark) based at the Animal and Grassland Research and Innovation Center. The generated spectrum, containing 1,060 transmittance data in the mid-infrared region between 900 and $5,000 \mathrm{~cm}^{-1}$, was stored. Mid-infrared spectroscopy models were developed using partial least squares regressions (PROC PLS; SAS Institute Inc., Cary, NC) with untreated spectra as described in detail by McDermott et al. (2016a). Spectral regions from 926 to $1,580 \mathrm{~cm}^{-1}, 1,717$ to $2,986 \mathrm{~cm}^{-1}$, and 3,696 to 3,808 $\mathrm{cm}^{-1}$ were used to develop all prediction models based on the observed loadings for each wavelength. In brief, between the years 2013 and 2014, a calibration data set was generated using 715 individual milk samples from the same 7 research herds used in the present study. Milk samples from 345 cows appeared in both data sets. Spectral outliers were determined as milk samples with a Mahalanobis distance greater than 3 (Williams, 2007) relative to the mean of the calibration data set. Prediction models were developed using 557 reference values for individual proteins and up to 715 reference values for FAA determined by HPLC. The accuracy (i.e., the coefficient of correlation) of prediction from (1) split-sample cross-validation and (2) external validation on an independent $25 \%$ of the data (not included in model calibration), as reported by McDermott et al. (2016a), is provided in Appendix Table A1. The accuracy of prediction in external validation was, on average, moderate; the coefficient of determination for protein fractions ranged from 0.39 ( $\beta$-LG A) to 0.74 (total $\mathrm{CN}$ ) and for FAA ranged from 0.26 (Arg) to 0.75 (Gly; McDermott et al., 2016a).

\section{Data Editing}

Spectral data with a Mahalanobis distance $>3$ (Williams, 2007) relative to the mean of the 715 samples used by McDermott et al. (2016a) to develop the prediction equations were considered as spectral outliers (1,634 milk samples in total) and discarded. Furthermore, predicted values of proteins and FAA that were $>3 \mathrm{SD}$ from the mean of the respective reference samples were considered to be outliers and removed as well. Milk yield over a 24-h period was available for the commercial cows; therefore, milk yield over a 24-h period was computed for the research cows as the sum of their morning and evening milk yields from the same day. Only records between 5 and 305 DIM and from parities $\leq 10$ were retained for analysis; parities $>5$ were grouped together for analysis.

Contemporary group of experimental treatment by test date was defined for milk samples from cows in 
research herds, whereas contemporary group of herd by test date was defined for milk samples from cows in commercial herds. Only records for contemporary groups with at least 10 records were retained for analysis. The research and commercial data sets were combined for analysis. After editing, the final data set comprised 134,546 milk spectra from 9,572 cows.

Pedigree data and breed composition of all animals were available from the national database managed by the Irish Cattle Breeding Federation (http://www.icbf. com). Only milk samples from Holstein (HO), Friesian (FR), Jersey (JE), Norwegian Red (NR), and Montbéliarde (MO) cows as well as their respective crosses (including progeny from crossbred parents of these breeds) were retained for analysis. The data consisted of 6,724 purebred cows (i.e., $\geq 75 \%$ pure), 2,848 crossbred cows, and 1,853 cows from crossbred parents. Table 1 lists the number of records, cows, and lactations and average parity of each breed and crossbreed. Coefficients of heterosis and recombination loss were calculated for each cow as

$$
\text { heterosis }=1-\sum_{i=1}^{n} \operatorname{sire}_{i} \times \operatorname{dam}_{i}
$$

and

$$
\text { recombination loss }=1-\sum_{i=1}^{n} \frac{\operatorname{sire}_{i}^{2}+\operatorname{dam}_{i}^{2}}{2}
$$

where $\operatorname{sire}_{i}$ and dam $_{i}$ are the proportion of genes of the breed $i$ in the sire and the dam, respectively (VanRaden and Sanders, 2003), and $n$ is the number of breeds.

\section{Data Analysis}

Factors associated with both protein and FAA composition traits were quantified separately using linear mixed models in ASReml (Gilmour et al., 2009). Factors considered in the model included the fixed effects of calendar month of milk test, milking time of the day (morning, evening, or both combined), parity $(1,2,3$, 4,5 , and $\geq 6$ ), stage of lactation (in 30-d intervals), an interaction between parity and stage of lactation, breed proportion of the cow fitted as separate covariates (FR, JE, NR, MO, and other), and general heterosis and recombination loss coefficients of the cow. Holstein breed proportion was not included in the model to avoid linear dependencies; therefore, breed solutions reported are relative to an $\mathrm{HO}$ cow. The random effects of contemporary group as well as within- and across-lactation effects were included in all models. Least squares means were estimated based on a reference cow represented as a $100 \% \mathrm{HO}$, third-parity cow, milked in the morning and averaged across stages of lactation and calendar months of the year of test. In a separate series of analyses, models with a protein fraction as the dependent variable were adjusted for total milk protein content (i.e., included as a covariate). Models with FAA as the dependent variable were adjusted for 24 -h milk yield by including 24 -h milk yield as a covariate in the models.

\section{RESULTS}

\section{Descriptive Statistics}

Mean predicted values of all milk traits in the research and commercial herds are summarized in Table 2. Mean values were similar for both the research and

Table 1. Number of records (n), cows, and lactations and the average parity for different breeds and crosses used in the present study

\begin{tabular}{lrrrc}
\hline Breed $^{1}$ & \multicolumn{1}{c}{$\mathrm{n}$} & Cows & Lactations & Parity \\
\hline $\mathrm{HO}$ & 62,653 & 6,562 & 10,568 & 2.7 \\
$\mathrm{FR}$ & 288 & 31 & 48 & 2.6 \\
$\mathrm{JE}$ & 4,872 & 63 & 107 & 2.22 \\
$\mathrm{NR}$ & 179 & 13 & 21 & 4.94 \\
$\mathrm{MO}$ & 135 & 55 & 81 & 4.46 \\
$\mathrm{HO} \times \mathrm{FR}$ & 34,690 & 1,826 & 2,954 & 2.68 \\
$\mathrm{HO} \times \mathrm{JE}$ & 24,204 & 488 & 851 & 2.07 \\
$\mathrm{HO} \times \mathrm{NR}$ & 2,280 & 271 & 501 & 3.65 \\
$\mathrm{HO} \times \mathrm{MO}$ & 728 & 122 & 188 & 2.79 \\
$\mathrm{JE} \times \mathrm{FR}$ & 2,823 & 67 & 117 & 2.25 \\
$\mathrm{JE} \times \mathrm{NR}$ & 1,518 & 51 & 1 & 2.29 \\
$\mathrm{JE} \times \mathrm{MO}$ & 51 & 1 & 20 & 4.28 \\
$\mathrm{NR} \times \mathrm{FR}$ & 75 & 10 & 17 & 17 \\
$\mathrm{MO} \times \mathrm{FR}$ & 50 & & & \\
\hline
\end{tabular}

${ }^{1} \mathrm{HO}=$ Holstein $; \mathrm{FR}=$ Friesian; JE $=$ Jersey; NR = Norwegian Red; MO = Montbéliarde; $\times$ indicates a cross of varying proportions of each breed. A purebred animal was deemed to be $\geq 75 \%$ of the breed. 
Table 2. Number of records (n), mean (SD), and CV of the studied traits predicted using mid-infrared spectroscopy in research and commercial herds

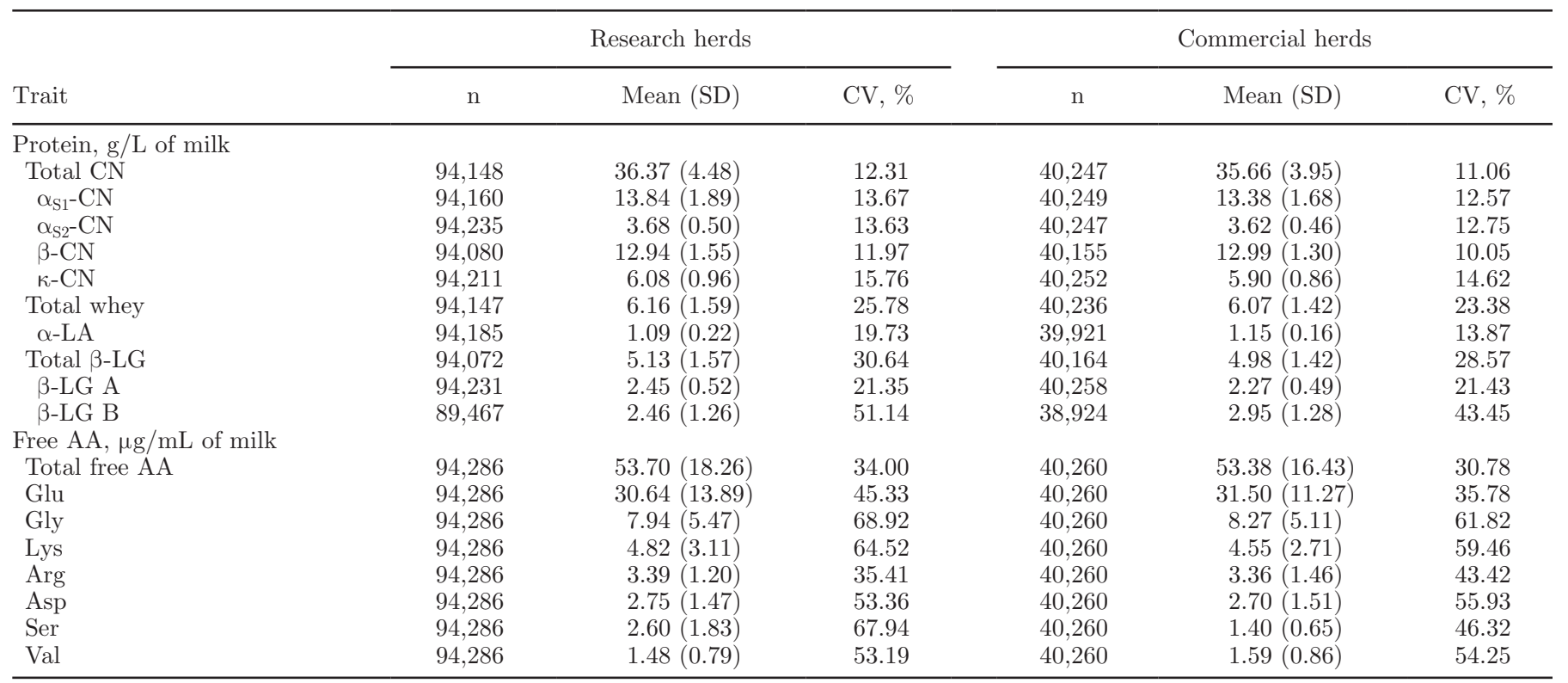

commercial herds. Mean values of total $\mathrm{CN}\left(\alpha_{\mathrm{S} 1}-\mathrm{CN}\right.$, $\alpha_{\mathrm{S}_{2}} \mathrm{CN}, \beta-\mathrm{CN}$, and $\left.\kappa-\mathrm{CN}\right)$ and total whey $(\alpha-\mathrm{LA}, \beta-\mathrm{LG}$ $\mathrm{A}$, and $\beta-\mathrm{LG} \mathrm{B}$ ) for both research and commercial herds were approximately in the ratio $6: 1$. Individual $\mathrm{CN}$ fractions $\left(\alpha_{\mathrm{S}^{-}} \mathrm{CN}, \alpha_{\mathrm{S} 2}-\mathrm{CN}, \beta-\mathrm{CN}\right.$, and $\left.\kappa-\mathrm{CN}\right)$ were present in the ratio 4:1:4:2 for both the research and commercial herds. The coefficient of variation differed among traits and ranged from $10 \%(\beta-\mathrm{CN})$ to $51 \%$ $(\beta-\mathrm{LG}-\mathrm{B})$ for the protein fractions. The FAA present in the greatest quantity in the milk was Glu, which represented $57 \%$ of total FAA (Glu, Gly, Lys, Arg, Asp, Ser, and Val) in the milk. Contemporary group accounted for between $45.34 \%$ (total FAA) and $86.11 \%(\alpha-\mathrm{LA})$ of the variability in the traits investigated.

\section{Nongenetic Factors}

Evening milk had a greater $(P<0.001)$ concentration of $\alpha_{S_{1}-} \mathrm{CN}, \alpha_{S 2} \mathrm{CN}$, total whey protein, $\alpha-\mathrm{LA}$, total $\beta-\mathrm{LG}$, and $\beta$-LG A but a reduced $(P<0.01)$ concentration of $\beta-\mathrm{CN}$ (13.60 vs. $13.75 \mathrm{~g} / \mathrm{L}$ ) compared with morning milk when adjusted for CP content (Table 3). Furthermore, although evening milk has more $(P<$ 0.01) $\beta$-CN than morning milk, the biological difference was small. Evening milk had a greater $(P<0.001)$ concentration of all FAA (total FAA, Glu, Gly, Lys, Arg, Asp, and Val) except Ser compared with morning milk when adjusted for milk yield (Table 3 ).

The observed interaction between stage of lactation and parity on the concentration of protein fractions persisted regardless of whether adjustments were made in the statistical model for either differences in $\mathrm{CP}$ content or 24-h milk yield (results not shown). When adjusted for $\mathrm{CP}$ content, total $\mathrm{CN}$ and protein fractions (except for $\alpha$-LA) decreased postcalving to between 36 and 65 DIM across all parities but gradually increased thereafter (Figures 1, 2, and 3). In younger cows, $\alpha$-LA in milk decreased between 5 and 155 DIM $(P<0.05)$ and then plateaued when adjusted for $\mathrm{CP}$ content; however, in older cows, $\alpha$-LA in milk remained constant until mid to late lactation, after which it decreased in concentration (Figure 3). Across all stages of lactation, younger animals produced milk with a greater concentration of total CN $(P<0.05)$, total whey $(P<0.001)$, and total $\beta$-LG $(P<0.001)$ than their older contemporaries when adjusted for $\mathrm{CP}$ content. Younger cows produced more $\alpha_{\mathrm{S} 1}-\mathrm{CN}(P<0.01)$ and $\beta-\mathrm{CN}(P<0.001)$ in milk than older cows, but first-parity cows produced less $\alpha_{\mathrm{S}_{2}} \mathrm{CN}$ (0.001) and $\mathrm{k}-\mathrm{CN}$ (0.01) than multiparous cows when adjusted for $\mathrm{CP}$ content.

Figure 4 illustrates the interaction between stage of lactation and parity $(P<0.001)$ on total FAA, Glu, Gly, and Lys concentration in milk adjusted for milk yield. Irrespective of cow parity, Lys and Val concentration decreased in milk until 36 to 65 DIM; subsequently, Lys concentration plateaued and Val concentration continued to increase across stage of lactation. Total FAA and Gly concentration decreased from 5 to 125 DIM, after which total FAA continued to decrease across stage of lactation in earlier parities but plateaued in later parities and Gly concentration plateaued irrespective of parity. Across stage of lactation, younger cows had 
Table 3. Least squares means (SE in parentheses) of individual protein fractions adjusted for CP content and of individual free AA ( $\mu \mathrm{g} / \mathrm{mL}$ of milk) adjusted for milk yield in both morning and evening milkings ${ }^{1}$

\begin{tabular}{|c|c|c|c|}
\hline \multirow[b]{2}{*}{ Item } & \multicolumn{2}{|c|}{ Milking time } & \multirow[b]{2}{*}{$P$-value } \\
\hline & Morning & Evening & \\
\hline \multicolumn{4}{|c|}{ Protein, $\mathrm{g} / \mathrm{L}$ of milk } \\
\hline Total CN & $38.43(0.0979)$ & $38.66(0.0983)$ & \\
\hline$\alpha_{\mathrm{S} 1}-\mathrm{CN}$ & $14.39(0.0414)$ & $14.80(0.0415)$ & $<0.001$ \\
\hline$\alpha_{\mathrm{S} 2-} \mathrm{CN}$ & $3.91(0.0105)$ & $3.99(0.0106)$ & $<0.001$ \\
\hline$\beta-\mathrm{CN}$ & $13.72(0.0323)$ & $13.60(0.0324)$ & $<0.01$ \\
\hline$\kappa-\mathrm{CN}$ & $6.55(0.0201)$ & $6.58(0.0202)$ & \\
\hline Total whey & $6.41(0.0372)$ & $6.68(0.0374)$ & $<0.001$ \\
\hline$\alpha-\mathrm{LA}$ & $1.13(0.0046)$ & $1.16(0.0047)$ & $<0.001$ \\
\hline Total $\beta$-LG & $5.33(0.0359)$ & $5.61(0.0360)$ & $<0.001$ \\
\hline$\beta$-LG A & $2.49(0.0125)$ & $2.61(0.0125)$ & $<0.001$ \\
\hline$\beta-L G$ B & $2.60(0.0360)$ & $2.70(0.0361)$ & $<0.05$ \\
\hline \multicolumn{4}{|c|}{ Free $\mathrm{AA}, \mu \mathrm{g} / \mathrm{mL}$ of milk } \\
\hline Total free AA & $53.73(0.3871)$ & $60.73(0.3890)$ & $<0.001$ \\
\hline Glu & $30.01(0.3138)$ & $34.09(0.3152)$ & $<0.001$ \\
\hline Gly & $7.84(0.0878)$ & $8.64(0.0886)$ & $<0.001$ \\
\hline Lys & $5.08(0.0646)$ & $5.87(0.0651)$ & $<0.001$ \\
\hline Arg & $3.53(0.0272)$ & $4.18(0.0274)$ & $<0.001$ \\
\hline Asp & $2.74(0.0313)$ & $3.17(0.0314)$ & $<0.001$ \\
\hline Ser & $2.93(0.0315)$ & $2.88(0.0318)$ & \\
\hline Val & $1.60(0.0185)$ & $1.79(0.0187)$ & $<0.001$ \\
\hline
\end{tabular}

${ }^{1}$ Commercial herds are not included.

a greater $(P<0.001)$ concentration of total FAA, Glu, and Asp in milk compared with older contemporaries. The concentration of Gly was the same across parities $(P<0.05)$, and the concentration of Lys and Arg was lower in earlier parities compared with later parities $(P$ $<0.001)$.

After adjusting for $\mathrm{CP}$ content, a peak in the concentration of all $\mathrm{CN}$ fractions was evident in the months of August, September, and October (Figure 5; $P<0.001$ ), whereas the concentration of $\alpha-\mathrm{LA}$ remained relatively constant across the year $(P<0.05)$. The concentration of Glu was greater $(P<0.001)$ during the months of February, March, April, and June, whereas the concentration of Gly was greater $(P<0.001)$ during the months of February, March, and June when adjusted for milk yield. The change in the concentration of Asp, Ser, and Val across calendar month of the year adjusted for milk yield was small but significant $(P<0.05)$.

\section{Breed, Heterosis, and Recombination Effects}

Table 4 provides breed regression coefficient estimates for concentration of proteins adjusted for $\mathrm{CP}$ content expressed relative to a purebred $\mathrm{HO}$ for $\mathrm{FR}$, JE, NR, and MO breeds and associated heterosis and recombination estimates. Milk produced by JE cows had the greatest concentration of all CN fractions $(P<0.001)$, and JE cows produced milk with $3.91,3.14,2.86$, and $4.64 \mathrm{~g} / \mathrm{L}$ more total $\mathrm{CN}$ than $\mathrm{HO}, \mathrm{FR}, \mathrm{NR}$, and MO cows, respectively. Also, JE cows produced milk that had a greater concentration of the $\mathrm{CN}$ fractions $\left(\alpha_{\mathrm{S1}^{-}}\right.$,
$\alpha_{\mathrm{S}^{-}}, \beta-$, and $\left.\kappa-\mathrm{CN}\right)$ in addition to a greater concentration of total whey, $\alpha-\mathrm{LA}$, total $\beta-\mathrm{LG}$, and $\beta-\mathrm{LG}$ A relative to HO cows. The concentration of total whey protein in milk of JE cows was $0.42,0.23,0.42$, and 0.53 $\mathrm{g} / \mathrm{L}$ greater compared with the milk of $\mathrm{HO}, \mathrm{FR}, \mathrm{NR}$, and MO cows, respectively. Milk produced by JE cows had less $(P<0.001)$ total FAA, Glu, Gly, and Asp than any other breed of cow, including HO (Table 5).

Both heterosis and recombination estimates for all traits were small in magnitude. Relative to the purebred parent average, first-cross cows produced milk that had $0.27 \mathrm{~g} / \mathrm{L}$ more total $\mathrm{CN}$ and $0.13 \mathrm{~g} / \mathrm{L}$ more $\beta-\mathrm{CN}$. Positive recombination estimates were observed for all protein fractions in milk. Heterosis estimates for all FAA (except Lys) in milk were not different from zero, and recombination estimates for all FAA were not different from zero.

\section{DISCUSSION}

The objective of the present study was to determine the factors associated with protein composition and FAA composition of bovine milk. In the present study, mean values of $\alpha_{\mathrm{S}^{-}}, \alpha_{\mathrm{S}^{-}}, \beta-$, and $\kappa_{-} \mathrm{CN}$ were in the ratio 4:1:4:2, which was not in agreement with results by Farrell et al. (2004), who documented a ratio of $3: 1: 3: 1$. However the ratio of total $\mathrm{CN}$ to total whey protein $(6: 1)$ in the present study was consistent with Farrell et al. (2004). The coefficient of variation for total whey protein and whey fractions in the present study was greater than that reported by De Marchi et 
a)

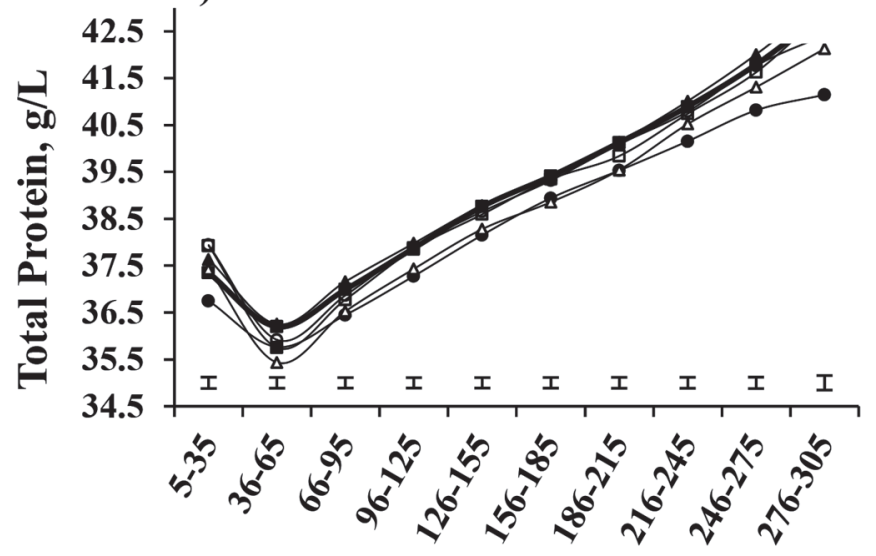

c)

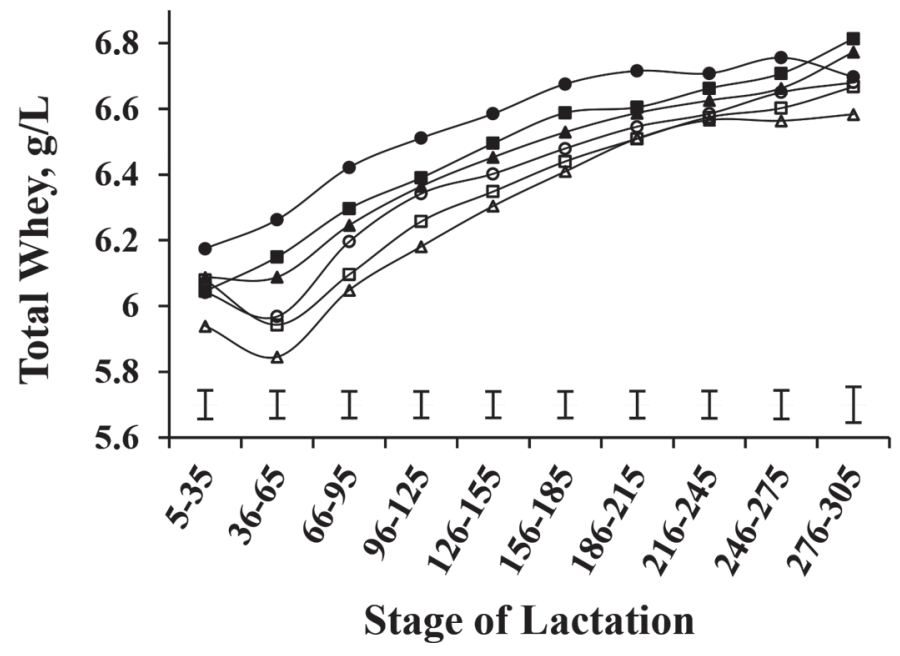

b)

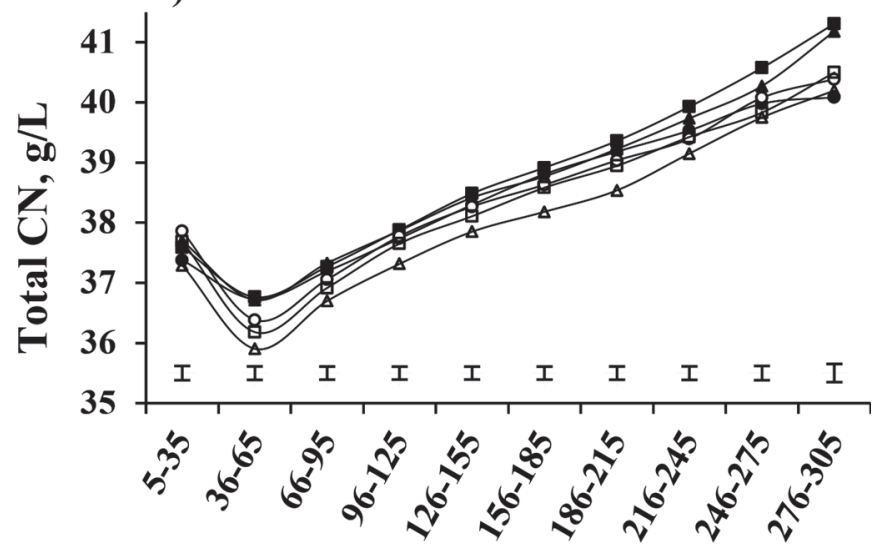

d)

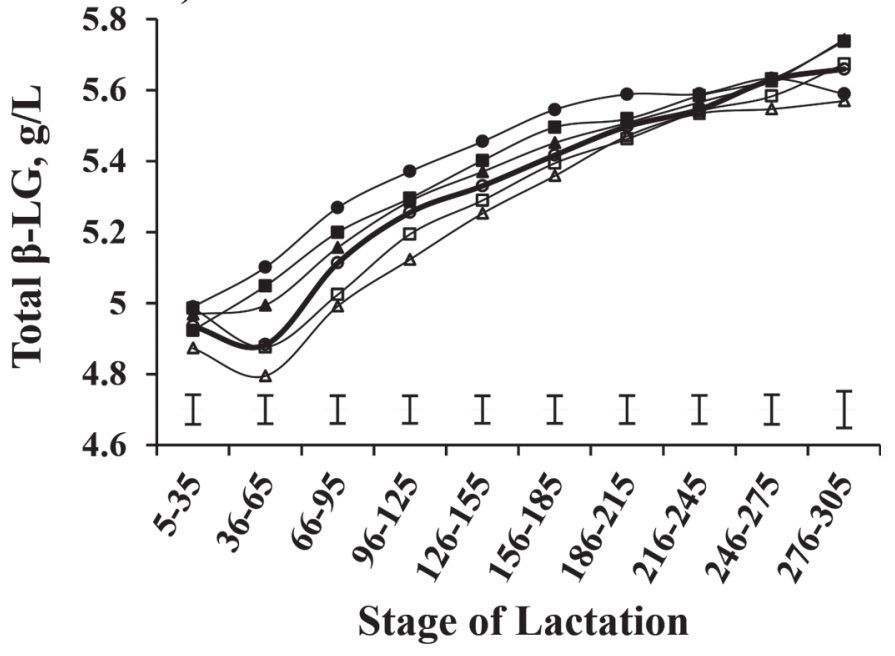

Figure 1. Trends in concentration of proteins in milk (a) total protein, (b) total CN, (c) total whey, and (d) total $\beta$-LG adjusted for CP content across stage of lactation for animals in parity $1(\bullet)$, parity $2(\boldsymbol{\square})$, parity $3(\mathbf{\Lambda})$, parity $4(\bigcirc)$, parity $5(\square)$, and parity $\geq 6(\Delta)$. Error bars represent the mean SE across parities.

al. (2010) for 1,336 Simmental cows only; the present study, however, contained records from cows of multiple breeds and crossbreds. Total mean proteins, determined using HPLC (42.53 g/L for the research herds; 41.73 $\mathrm{g} / \mathrm{L}$ for the commercial herds), were higher than those recorded using MIRS (37.45 g/L for the research herds; $36.67 \mathrm{~g} / \mathrm{L}$ for the commercial herds). This is most likely attributable to cumulative variation during summation of the individual protein values when integrating peak areas from the HPLC data (McDermott et al., 2016a). De Marchi et al. (2010) and Bonfatti et al. (2011) also reported high mean protein values using HPLC (i.e., up to 40.12 and $40.68 \mathrm{~g} / \mathrm{L}$, respectively) in milk from Simmental cows.

Similar trends across stage of lactation for $\alpha_{\mathrm{S}^{-}} \mathrm{CN}$, $\beta$-CN, $\beta$-LG, and $\alpha$-LA in milk adjusted for CP content (i.e., decrease in early lactation followed by a gradual increase) were observed both in the present study and elsewhere (Ng-Kwai-Hang et al., 1987). Kroeker et al. (1985) observed a similar stage of lactation trend when $\beta-\mathrm{CN}$ was expressed relative to total CN. The observed decline in total proteins and protein fractions in early lactation coincides with the period of negative energy balance typically seen in dairy cows in early lactation (Berry et al., 2006); negative protein balance (when the quantity of protein broken down by the cow exceeds the quantity ingested) may also occur. It can take a cow up to 20 wk to regain a positive energy and protein balance and for actual milk protein content to increase again (Taylor et al., 2003).

The reduction in concentration of total FAA and the individual FAA (Glu, Gly, Lys, Arg, and Asp) in milk up to $65 \mathrm{~d}$ postcalving corroborates documented reports by Ghadimi and Pecora (1963), who studied the 
a)

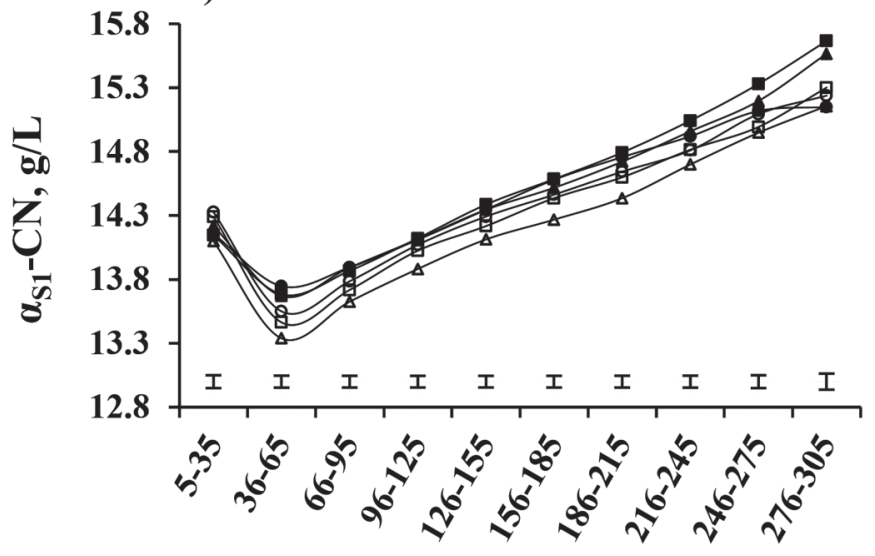

c)

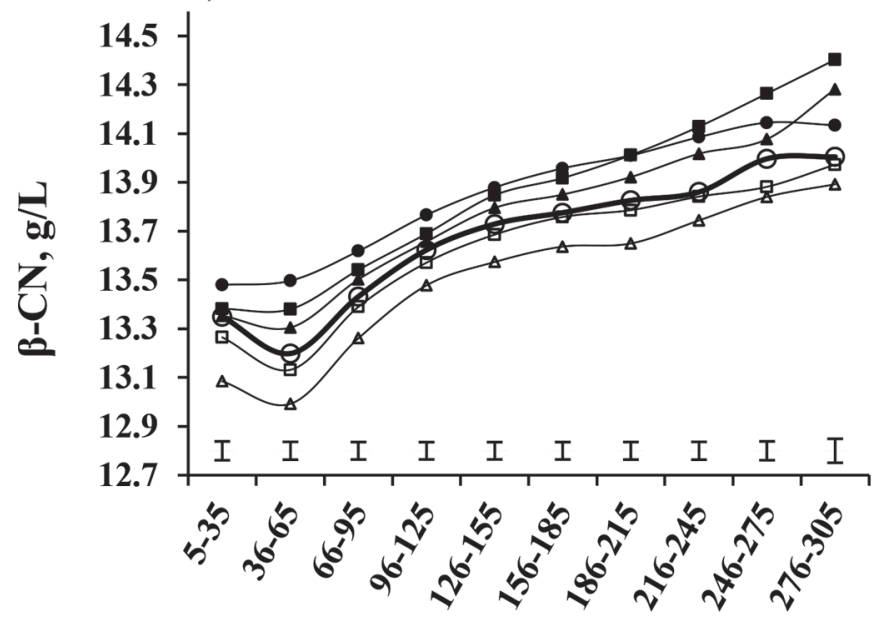

Stage of Lactation b)

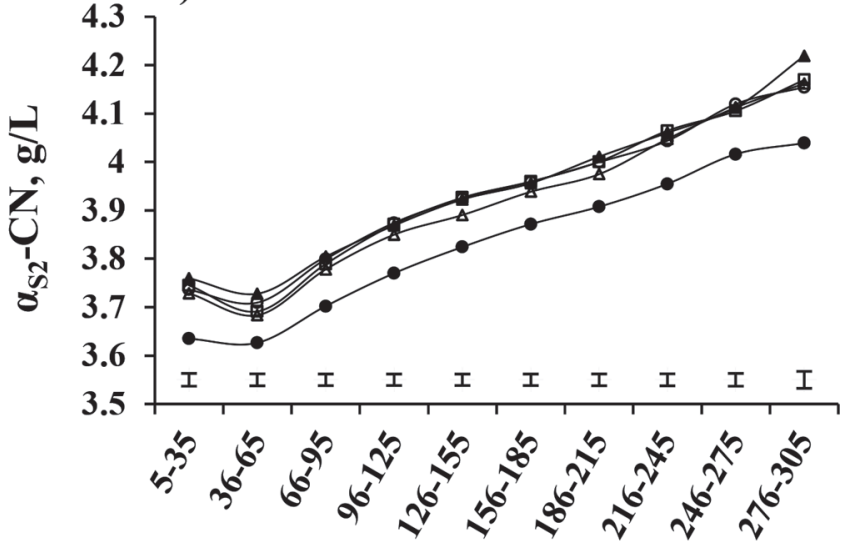

d)

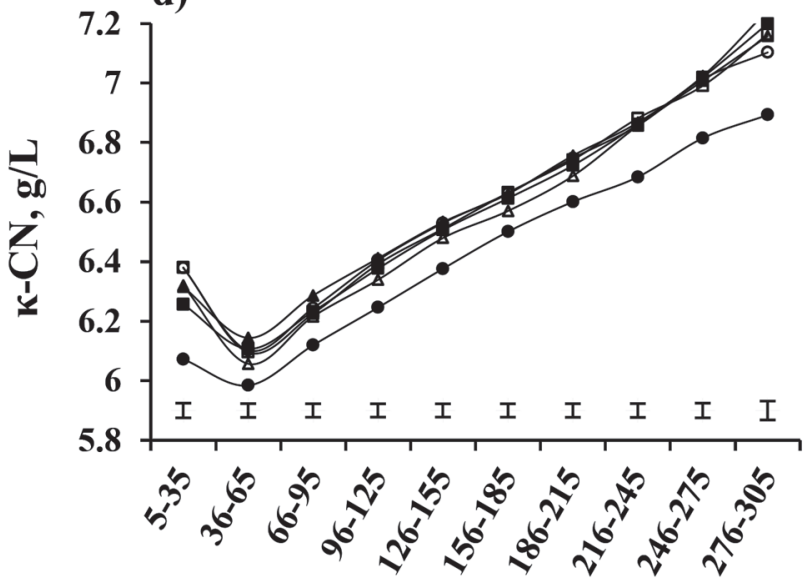

Stage of Lactation

Figure 2. Trends in concentrations of $\mathrm{CN}$ fractions in milk (a) $\alpha_{\mathrm{S} 1} \mathrm{CN}$, (b) $\alpha_{\mathrm{S}^{2}-} \mathrm{CN}$, (c) $\beta$-CN, and (d) $\kappa$-CN adjusted for $\mathrm{CP}$ content across stage of lactation for animals in parity $1(\bullet)$, parity $2(\boldsymbol{\square})$, parity $3(\boldsymbol{\Lambda})$, parity $4(\bigcirc)$, parity $5(\square)$, and parity $\geq 6(\Delta)$. Error bars represent the mean SE across parities.

concentration of these FAA in bovine milk from 7 to 60 DIM. Both total FAA and Glu in milk decreased as parity increased and, despite the part-whole relationship between them (Glu makes up $>55 \%$ of total FAA), the lactation profile of Glu and total FAA in milk differed in younger animals (Figure 4). To our knowledge, no study to date has investigated the association between parity and FAA composition of milk.

\section{Variability in Milk Quality}

Considerable variability in protein fractions and FAA existed in both populations studied. The coefficient of variation of $\beta$-LG B and Gly was 51 and $69 \%$, respectively, in the research herds, which is considerably greater than the coefficient of variation of $31 \%$ observed for milk yield in the same population (results not shown). The potential of milk MIRS to predict protein fractions and FAA (McDermott et al., 2016a) provides an opportunity to generate large quantities of data for use in genetic evaluations and thus breeding programs. The attributes and tools therefore appear to exist to facilitate breeding programs for superior milk quality characteristics if such characteristics are deemed to be heritable.

Contemporary group accounted for between $45.34 \%$ (total FAA) and $86.11 \%(\alpha-L A)$ of the variation in the data set used in this study, indicating that the combination of herd and test date has large effects on both protein and FAA composition of the milk. These differences offer the potential for herds to be selected on the basis of their protein and FAA profile; further 
milk price premiums could be paid to herds that are producing milk with a protein or FAA profile that better fits the processor's needs for production. Herd-level estimates of milk quality can be readily obtained as a by-product from national genetic evaluations, and thus the data can be readily available. These herd solutions would be independent of genetic merit of the producing animals and therefore more closely reflect the influence of management on milk quality. Moreover, the ability to monitor the trend in milk quality over time within a herd would help provide producers and processors with information to help support their decisions about the factors affecting the quality of their milk.

a)

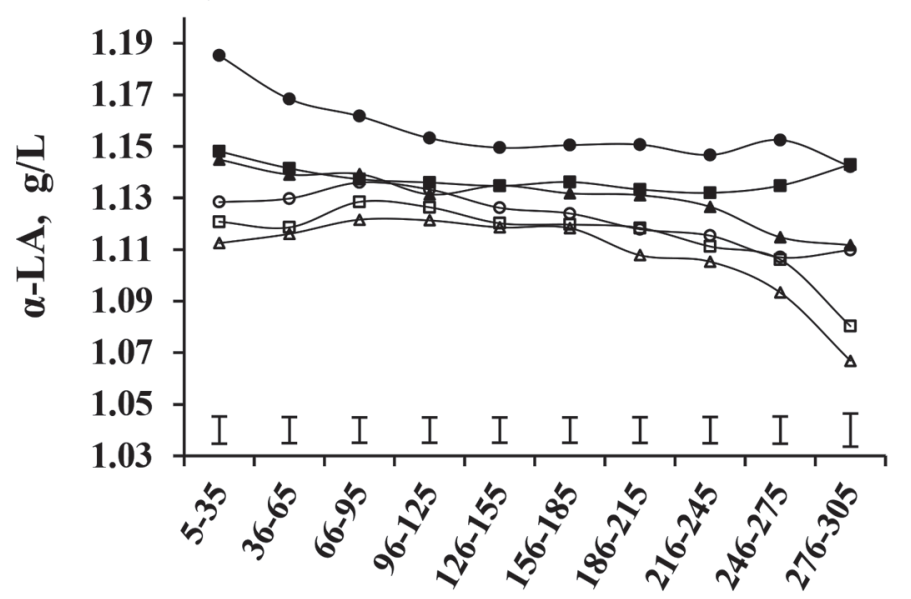

c)

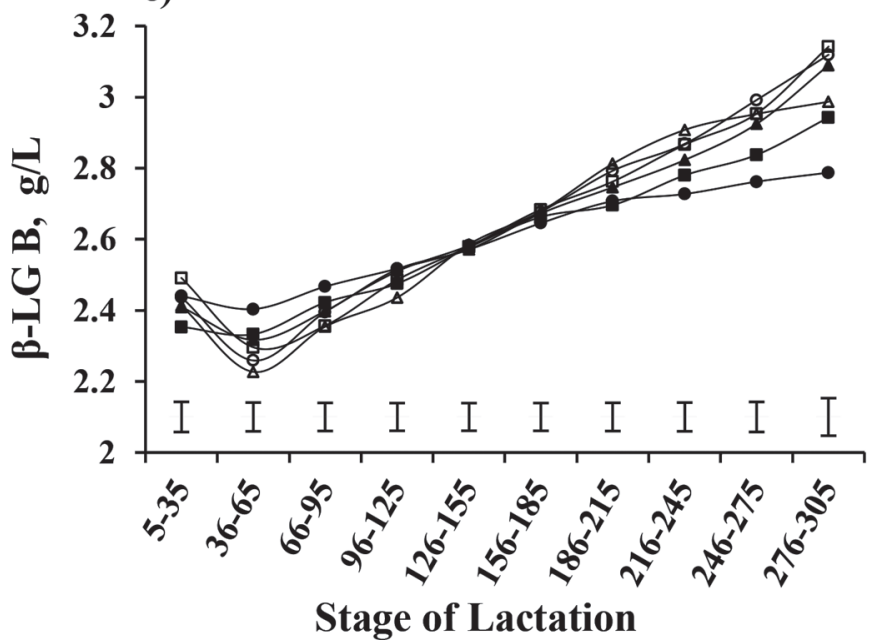

\section{Decision Support Tool}

The observed trends in milk protein fractions and FAA across month of the year (Figure 5) suggest differences in the suitability of milk for producing milk products across the year and provide evidence of the difficulty in acquiring a stable product of constant composition across time. The effect on consistency of product is further compounded in seasonal calving herds that exist in Ireland (Berry et al., 2013) and elsewhere because milk protein fractions and FAA also vary across stage of lactation, which is synchronized with calendar month. The structure of the data, coupled with the statisti-

b)

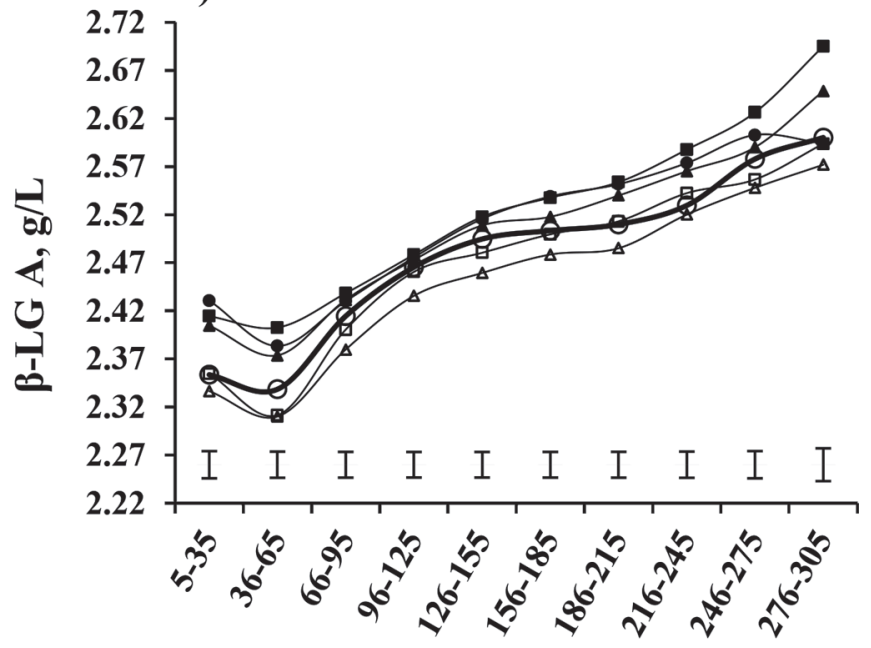

Stage of Lactation

Figure 3. Trends in concentrations of whey proteins in milk (a) $\alpha$-LA, (b) $\beta$-LG A, and (c) $\beta$-LG B adjusted for CP content across stage of lactation for animals in parity $1(\bullet)$, parity $2(\boldsymbol{\square})$, parity $3(\boldsymbol{\Delta})$, parity $4(\bigcirc)$, parity $5(\square)$, and parity $\geq 6(\Delta)$. Error bars represent the mean SE across parities. 


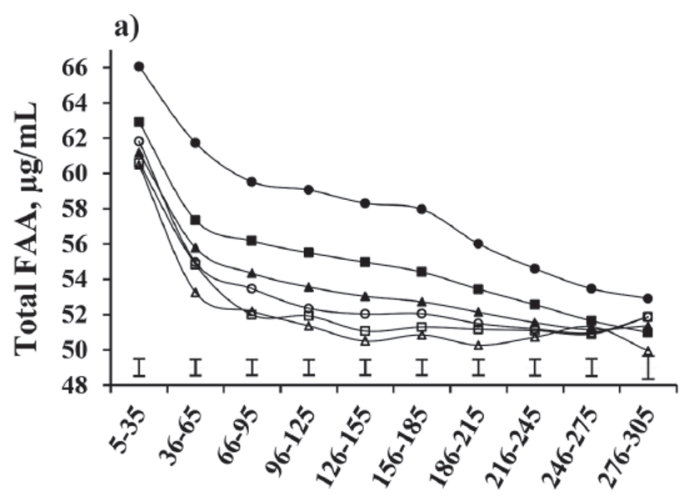

c)

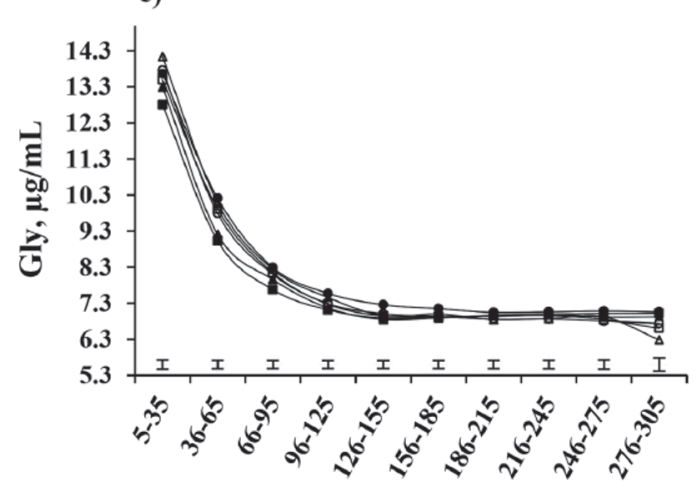

e)

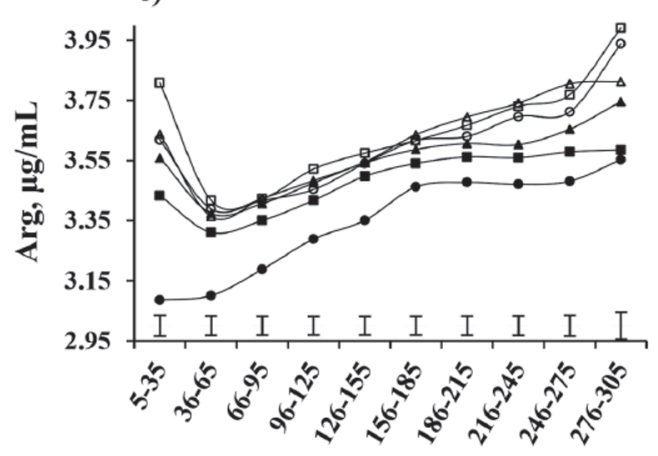

g)

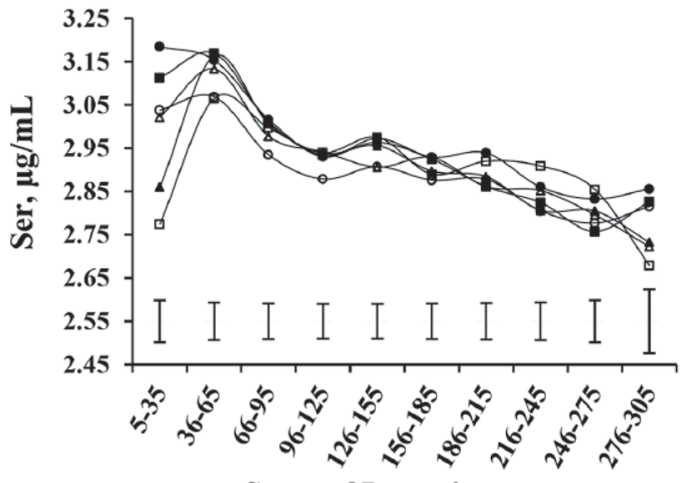

b)

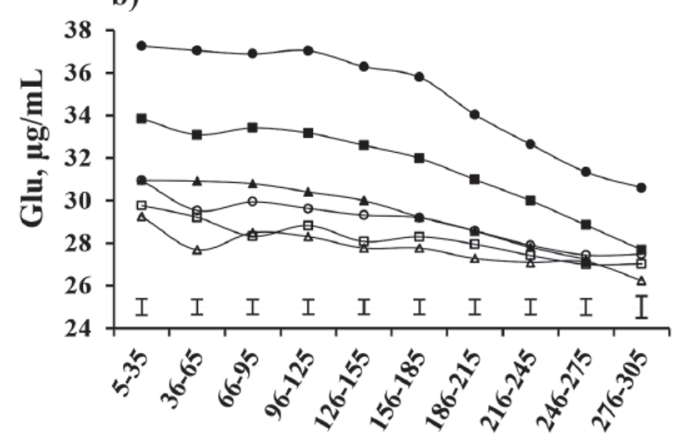

d)
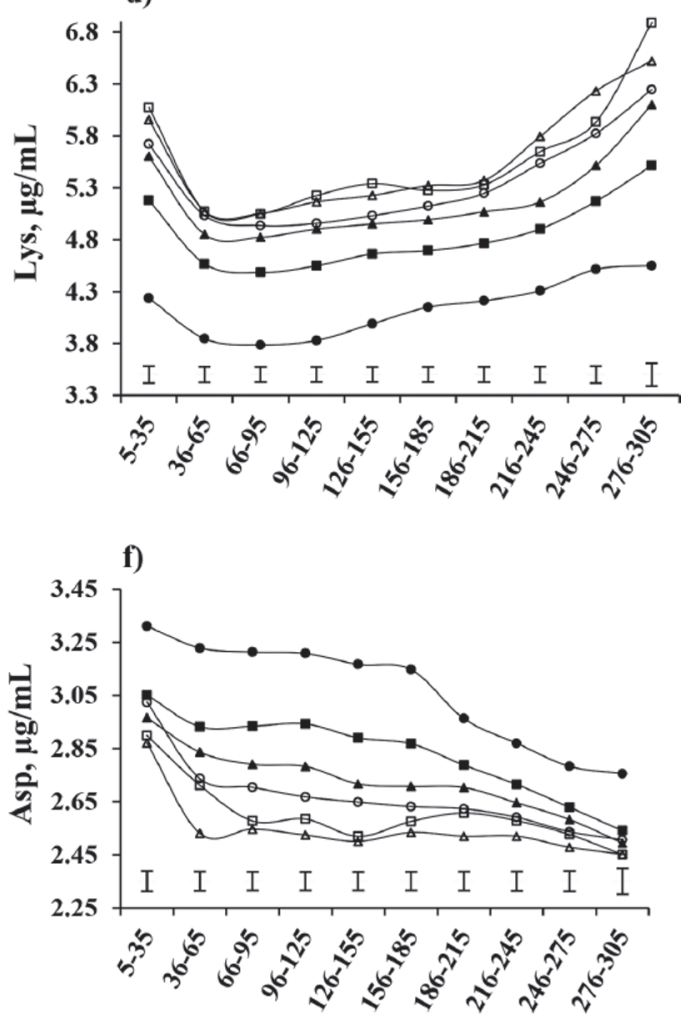

h)

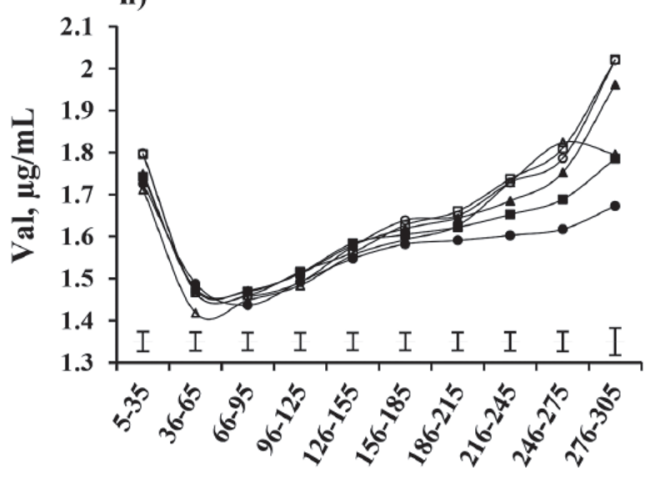

Stage of Lactation

Figure 4. Trends in total and individual free AA (FAA) in milk (a) total FAA, (b) Glu, (c) Gly, (d) Lys, (e) Arg, (f) Asp, (g) Ser, and (h) Val adjusted for milk yield across stage of lactation for animals in parity $1(\bullet)$, parity $2(\boldsymbol{\square})$, parity $3(\boldsymbol{\Lambda})$, parity $4(\bigcirc)$, parity $5(\square)$, and parity $\geq 6(\Delta)$. Error bars represent the mean SE across parities. 
Table 4. Breed regression coefficient estimates (SE in parentheses) for concentration of proteins ( $\mathrm{g} / \mathrm{L}$ of milk) adjusted for CP content expressed relative to a purebred Holstein (HO) for Friesian (FR), Jersey (JE), Norwegian Red (NR), and Montbéliarde (MO) breeds and associated heterosis and recombination estimates

\begin{tabular}{|c|c|c|c|c|c|c|c|}
\hline Item & $\mathrm{HO}$ & FR & $\mathrm{JE}$ & NR & MO & Heterosis & Recombination \\
\hline$\alpha_{\mathrm{S}_{1}-\mathrm{CN}}$ & $0^{\mathrm{a}}$ & $0.32^{\mathrm{b}}(0.09)$ & $1.72^{\mathrm{c}}(0.08)$ & $0.49^{\mathrm{b}}(0.12)$ & $-0.38^{\mathrm{d}}(0.14)$ & $0.10(0.05)^{*}$ & $0.50(0.07)^{*}$ \\
\hline$\alpha_{\mathrm{S} 2}-\mathrm{CN}$ & $0^{\mathrm{a}}$ & $0.06^{\mathrm{b}}(0.02)$ & $0.42^{\mathrm{c}}(0.02)$ & $0.06^{\mathrm{b}}(0.03)$ & $-0.08^{\mathrm{d}}(0.03)$ & $0.02(0.01)^{*}$ & $0.07(0.02)^{*}$ \\
\hline$\kappa-\mathrm{CN}$ & $0^{\mathrm{a}}$ & $0.07^{\mathrm{ab}}(0.04)$ & $0.69^{c}(0.04)$ & $0.19^{\mathrm{b}}(0.05)$ & $-0.08^{\mathrm{a}}(0.06)$ & $0.03(0.02)$ & $0.14(0.03)^{*}$ \\
\hline Total whey & $0^{\mathrm{a}}$ & $0.19^{\mathrm{b}}(0.07)$ & $0.42^{\mathrm{c}}(0.07)$ & $0.00^{\mathrm{ab}}(0.10)$ & $-0.11^{\mathrm{a}}(0.11)$ & $-0.04(0.04)$ & $0.22(0.06)^{*}$ \\
\hline$\alpha-\mathrm{LA}$ & $0^{\mathrm{a}}$ & $0.03^{\mathrm{b}}(0.01)$ & $0.08^{\mathrm{c}}(0.01)$ & $0.01^{\mathrm{ab}}(0.01)$ & $-0.01^{\mathrm{ab}}(0.01)$ & $0.01(0.01)$ & $0.03(0.00)^{*}$ \\
\hline$\beta-L G$ B & 0 & $0.11(0.08)$ & $-0.04(0.07)$ & $-0.09(0.11)$ & $0.09(0.12)$ & $-0.09(0.04)^{*}$ & $0.13(0.06)^{*}$ \\
\hline
\end{tabular}

${ }^{\mathrm{a}-\mathrm{d}}$ Values within a row with different superscripts differ $(P<0.05)$.

*Regression coefficients significantly differ from zero $(P<0.05)$.

cal model, implies that the observed effects reported in the present study are independent of each other and are therefore additive. Commercially available infant formulas have a ratio of total $\mathrm{CN}$ to total whey protein that is close to that of human milk, but $\beta-L G$, which is not present in human milk, is present in the greatest amount in cow milk. It is advantageous for infant formula producers to select cow milk with a higher concentration of $\alpha$-LA and a lower concentration of $\beta$-LG. Figure 3 demonstrates that earlier parity animals in early lactation produce the highest concentration of $\alpha$-LA. Results from the present study also show that milk produced by young JE cows in the months of August, September, and October could achieve a greater concentration of $\mathrm{CN}$ fractions in milk.

Bovine and human milk also differ in their amino acid profiles (Chuang et al., 2005); for example, human milk has on average 4 times more Arg and twice as much Tau as bovine milk (Sarwar et al., 1998). Free amino acids are often added to infant formula by pro- a)

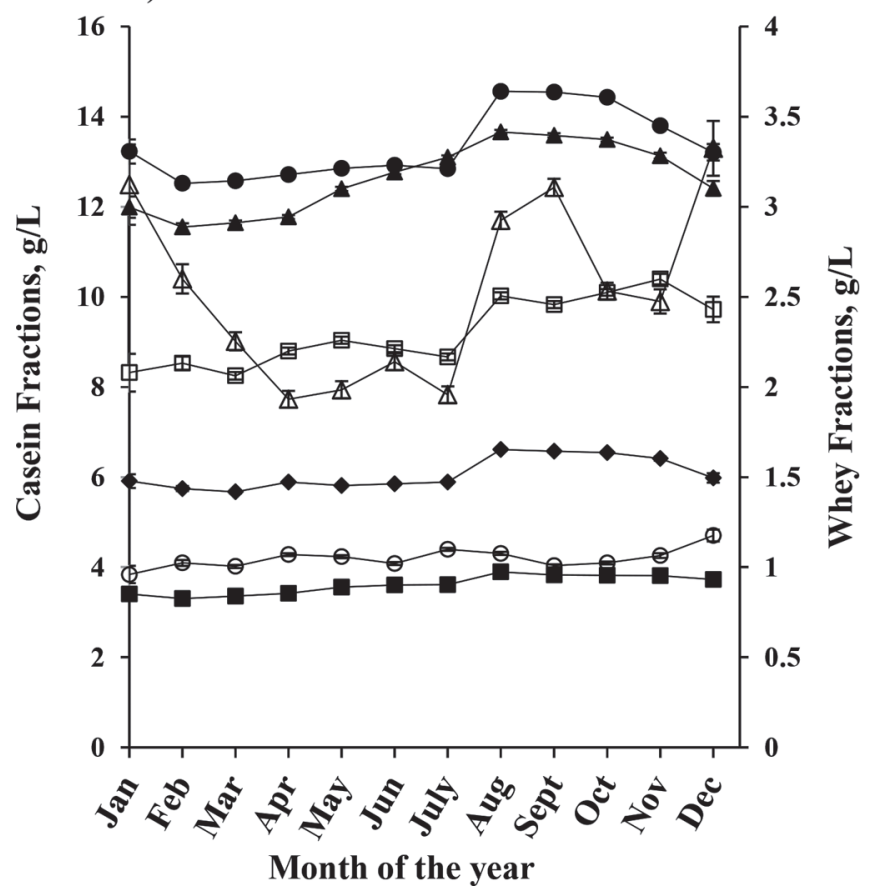

b)

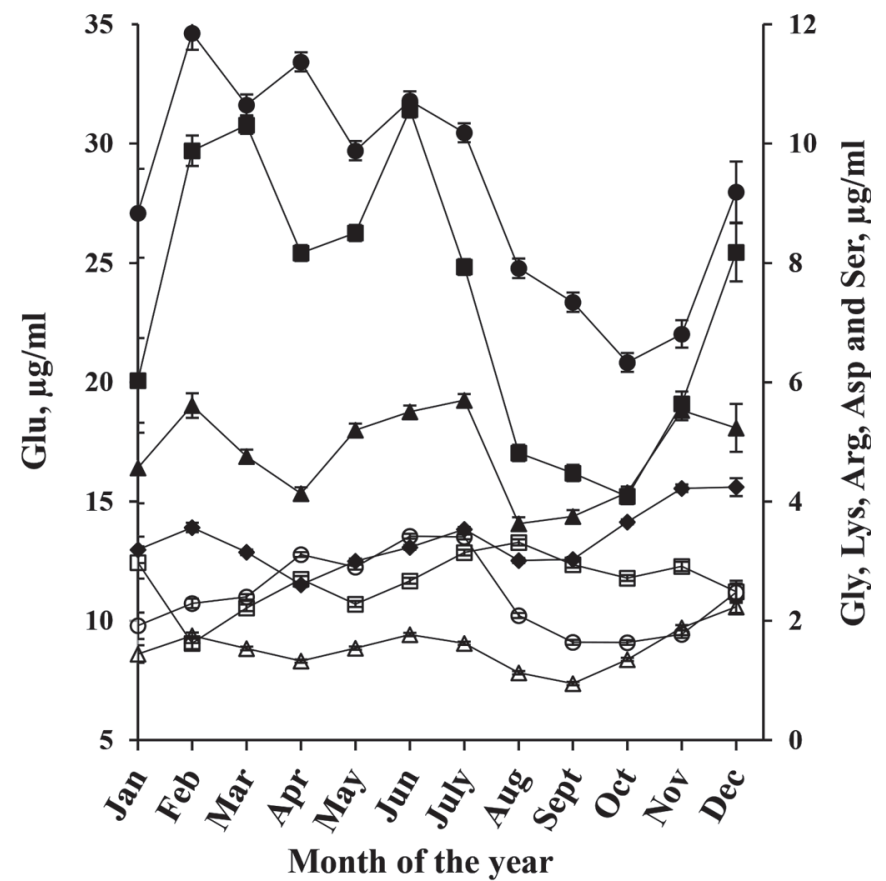

Figure 5. (a) Least squares means of concentrations (g/L of milk) of $\mathrm{CN}$ fractions [primary vertical axis; $\alpha_{\mathrm{S}^{-}} \mathrm{CN}(\boldsymbol{\bullet}), \alpha_{\mathrm{S} 2^{-}} \mathrm{CN}(\boldsymbol{\square}), \beta-\mathrm{CN}(\boldsymbol{\Delta})$, and $\kappa-\mathrm{CN}(\bullet)$ ] and whey fractions [secondary vertical axis; $\alpha$-LA $(\bigcirc), \beta-\mathrm{LG} \mathrm{A}(\square)$, and $\beta$-LG B $(\Delta)$ ] adjusted for total milk protein content across calendar month of the year. (b) Least squares means of concentrations ( $\mu \mathrm{g} / \mathrm{mL}$ of milk) of Glu (-; primary vertical axis) and Gly ( $\mathbf{\square}$ ), Lys $(\boldsymbol{\Lambda}), \operatorname{Arg}(\bullet), \operatorname{Asp}(\bigcirc)$, Ser $(\square)$, and Val $(\Delta$; all on the secondary vertical axis) in milk adjusted for milk yield across calendar month of the year. Error bars represent SE. 
Table 5. Breed regression coefficient estimates (SE in parentheses) for concentration of free AA ( $\mu \mathrm{g} / \mathrm{mL}$ of milk) adjusted for milk yield expressed relative to a purebred Holstein (HO) for Friesian (FR), Jersey (JE), Norwegian Red (NR), and Montbéliarde (MO) breeds and associated heterosis and recombination estimates

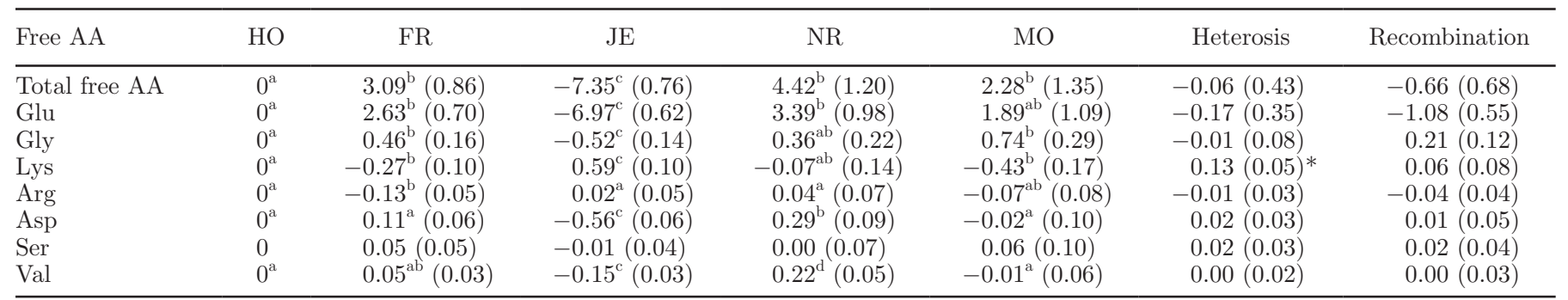

${ }^{\mathrm{a}-\mathrm{d}}$ Values within a row with different superscripts differ $(P<0.05)$.

$*$ Regression coefficients significantly differ from zero $(P<0.05)$.

cessors, especially for the production of formula for infants with allergies to $\mathrm{CN}$ and whey protein fractions in milk (Owens et al., 2012). Results from the present study may also help infant formula processors select milk that is naturally higher in the sought-after protein or FAA profile, thereby minimizing the requirement for protein and FAA additives.

Previous studies have revealed that greater concentrations of all $\mathrm{CN}$ fractions in milk significantly increase cheese yield (Wedholm et al., 2006), and rennet coagulating time is positively correlated with the contents and proportions of $\alpha_{\mathrm{S}^{-}}$and $\alpha_{\mathrm{S} 2^{-}} \mathrm{CN}$ in total CN (Bonfatti et al., 2011). Figures 2 and 3 indicate that the concentration of certain protein fractions $\left(\alpha_{\mathrm{S}_{1}} \mathrm{CN}, \beta-\mathrm{CN}\right.$, $\kappa-\mathrm{CN}$, and $\beta$-LG B) in early lactation could possibly be too low for cheese production; this could be useful information for cheese manufacturers to optimize quality and yield of cheese. Mid- and late-lactation milk has a greater concentration of $\kappa$-CN than early-lactation milk, and first-parity animals have a lower concentration of $\kappa-\mathrm{CN}$ than their older contemporaries. A higher concentration of $\kappa-\mathrm{CN}$ in milk results in a smaller $\mathrm{CN}$ micelle (Gutiérrez-Adán et al., 1996) and therefore in a shorter rennet coagulation time, contributing to a stronger curd and more cheese yield. However, it is the genetic polymorphism of $\kappa-\mathrm{CN} \mathrm{B}$ that is of importance (Ikonen et al., 1999), suggesting that a way to improve milk process ability for cheese production would be to select animals with genes coding for $\mathrm{k}-\mathrm{CN} \mathrm{B}$. Jersey cows produced more $\mathrm{CN}$ fractions but less total FAA in milk compared with $\mathrm{HO}$ cows, indicating that JE cows may produce milk that is more suitable for cheese production and of a better processing quality than $\mathrm{HO}$ cows.

\section{Crossbreeding}

Heterosis is defined as the difference between the performance of a crossbred animal and the average of the parents (Willham and Pollak, 1985). Relative to the purebred parent average, first-cross cows produced $0.13 \mathrm{~g} / \mathrm{L}$ more $\beta-\mathrm{CN}$. Studies have indicated that the consumption of $\beta-\mathrm{CN}$ A1 is associated with higher mortality rates from coronary heart disease in humans (McLachlan, 2001; Laugesen and Elliott, 2003). However, further research is required to determine the genetic composition of $\beta-\mathrm{CN}$ in the milk analyzed in the present study based on its genetic composition. Recombination loss is defined as the disintegration of epistatic associations to form nonparent interloci combinations of alleles in crossbred animals (Cassady et al., 2002). Generally, recombination has unfavorable effects on milk compositional traits such as protein (Dechow et al., 2007), even though favorable recombination estimates were calculated for concentrations of all the individual protein fractions (total $\mathrm{CN}, \alpha_{\mathrm{S}^{-}} \mathrm{CN}, \alpha_{\mathrm{S} 2}-\mathrm{CN}$, $\beta-\mathrm{CN}, \kappa-\mathrm{CN}$, total $\beta$-LG, $\beta$-LG A, and $\beta$-LG B) in milk. An unfavorable effect is expected because recombination normally affects traits such as milk production that have been under long-term selection intensity ( $\mathrm{S} \phi$ rensen et al., 2008). However, a study by Coffey et al. (2016) showed recombination to have positive effects on milk compositional traits, including protein percentage, and suggested that different population breeding goals may be a causative factor in the inconsistencies among studies on the effect of recombination on milk compositional traits. Traditionally, Irish dairy cows may have been naturally selected for fertility and survivability as a result of the seasonal calving system operated in Ireland (Berry et al., 2013), therefore reducing the selection pressure on milk composition traits. Although crossbreeding has known advantages (Buckley et al., 2014; Coffey et al., 2016), crossbreeding of dairy cattle is not commonly practiced worldwide (Buckley et al., 2014). Results from the present study indicate that crossbred cows had a greater concentration of $\beta-\mathrm{CN}$ in milk than purebred $\mathrm{HO}$, which is advantageous for cheese production, thus demonstrating another advantage of crossbreeding. 


\section{CONCLUSIONS}

Results from the present study indicate that factors including stage of lactation, parity, calendar month of the year, milking time, and breed are all associated with protein and FAA composition of bovine milk. Of particular interest was that younger animals produced more total $\mathrm{CN}$, total whey, and total $\beta-\mathrm{LG}$ across early and mid lactation and more Glu and Asp in milk across lactation than their older contemporaries. Milk produced by JE cows had a greater concentration of all $\mathrm{CN}$ fractions but a lower concentration of total FAA than that produced by HO cows. This study provides information on how individual milk proteins and FAA change across calendar months of the year and across stages of lactation, which could be useful input parameters for decision support tools in the management of product portfolios by processors over time.

\section{ACKNOWLEDGMENTS}

Funding for this work was provided by the Irish Department of Agriculture, Food and the Marine (Dublin, Ireland) Research Stimulus Fund project 11/SF/311, Breed Quality.

\section{REFERENCES}

Auldist, M. J., S. Coats, G. L. Rogers, and G. H. McDowell. 1995. Changes in composition of milk from healthy and mastitic cows during the lactation cycle. Aust. J. Exp. Agric. 35:427-436.

Auldist, M. J., K. A. Johnston, N. J. White, W. P. Fitzsimons, and M. J. Boland. 2004. A comparison of the composition, coagulation characteristics and cheese making capacity of milk from Friesian and Jersey dairy cows. J. Dairy Res. 71:51-57.

Berry, D. P., J. F. Kearney, K. Twomey, and R. D. Evans. 2013. Genetics of reproductive performance in seasonal calving dairy cattle production systems. Ir. J. Agric. Food Res. 52:1-16.

Berry, D. P., R. F. Veerkamp, and P. Dillon. 2006. Phenotypic profiles for body weight, body condition score, energy intake, and energy balance across different parities and concentrate feeding levels. Livest. Sci. 104:1-12.

Bonfatti, V., G. Di Martino, and P. Carnier. 2011. Effectiveness of mid-infrared spectroscopy for the prediction of detailed protein composition and contents of protein genetic variants of individual milk of Simmental cows. J. Dairy Sci. 94:5776-5785.

Buckley, F., N. Lopez-Villalobos, and B. J. Heins. 2014. Crossbreeding: Implications for dairy cow fertility and survival. Animal 8:122-133.

Cassady, J. P., L. D. Young, and K. A. Leymaster. 2002. Heterosis and recombination associations on pig reproductive traits. J. Anim. Sci. 80:2303-2315.

Chuang, C. K., S. P. Lin, H. C. Lee, T. J. Wang, Y. S. Shih, K. Y. Huang, and C. Y. Yeung. 2005. Free amino acids in full-term and pre-term human milk and infant formula. J. Pediatr. Gastroenterol. Nutr. 40:496-500.

Coffey, E. L., B. Horan, R. D. Evans, and D. P. Berry. 2016. Milk production and fertility performance of Holstein, Friesian, and Jersey purebred cows and their respective crosses in seasonal-calving commercial farms. J. Dairy Sci. 99:5681-5689.

De Marchi, M., V. Bonfatti, A. Cecchinato, G. Di Martino, and P. Carnier. 2010. Prediction of protein composition of individual cow milk using mid-infrared spectroscopy. Ital. J. Anim. Sci. 8(Suppl. 2):399-401.

De Marchi, M., V. Toffanin, M. Cassandro, and M. Penasa. 2014. Invited review: Mid-infrared spectroscopy as a phenotyping tool for milk traits. J. Dairy Sci. 97:1171-1186.

Dechow, C. D., G. W. Rogers, J. B. Cooper, M. I. Phelps, and A. L. Mosholder. 2007. Milk, fat, protein, somatic cell score, and days open among Holstein, Brown Swiss, and their crosses. J. Dairy Sci. 90:3542-3549.

DePeters, E. J., and J. D. Ferguson. 1992. Nonprotein nitrogen and protein distribution in the milk of cows. J. Dairy Sci. 75:3192-3209.

Farrell, H. M., R. Jimenez-Flores, G. T. Bleck, E. M. Brown, J. E. Butler, L. K. Creamer, C. L. Hicks, C. M. Hollar, K. F. Ng-KwaiHang, and H. E. Swalsgood. 2004. Nomenclature of the proteins of cows' milk - Sixth revision. J. Dairy Sci. 87:1641-1674.

Ghadimi, H., and P. Pecora. 1963. Free amino acids of different kinds of milk. Am. J. Clin. Nutr. 13:75-81.

Gilmour, A. R., B. R. Cullis, S. J. Wellham, and R. Thompson. 2009. ASREML Reference Manual. VSN International Ltd., Hemel Hempstead, UK.

Gleeson, M. 2008. Dosing and efficacy of glutamine supplementation in human exercise and sport training. J. Nutr. 138:2045S-2049S.

Gutiérrez-Adán, A., E. A. Maga, H. Meade, C. F. Shoemaker, J. F. Medrano, G. B. Anderson, and J. D. Murray. 1996. Alterations of the physical characteristics of milk from transgenic mice producing bovine א-casein. J. Dairy Sci. 79:791-799.

Ikonen, T., K. Ahlfors, R. Kempe, M. Ojala, and O. Ruottinen. 1999 Genetic parameters for the milk coagulation properties and prevalence of noncoagulating milk in Finnish dairy cows. J. Dairy Sci $82: 205-214$.

Ikonen, T., S. Morry, A. M. Tyriseva, O. Routtinen, and M. Ojala. 2004. Genetic and phenotypic correlations between milk coagulation properties, milk production traits, somatic cell count, casein content, and pH of milk. J. Dairy Sci. 87:458-467.

Joudu, I., M. Henno, T. Kaart, T. Pussa, and O. Kart. 2008. The association of milk protein contents on the rennet coagulation properties of milk from individual dairy cows. Int. Dairy J. 18:964-967.

Kroeker, E. M., K. F. Ng-Kwai-Hang, J. F. Hayes, and J. E. Moxley. 1985. Associations of environmental factors and milk protein polymorphism on composition of casein fraction in bovine milk. J. Dairy Sci. 68:1752-1757.

Laugesen, M., and R. Elliott. 2003. Ischaemic heart disease, type 1 diabetes, and cow milk A1 beta-casein. N. Z. Med. J. 116:U295.

Lopez-Villalobos, N. 2012. Analysing the genetic basis of milk production traits. CAB Rev. 5167:1-18.

McDermott, A., G. Visentin, M. De Marchi, D. P. Berry, M. A. Fenelon, P. M. O'Connor, O. A. Kenny, and S. McParland. 2016a. Prediction of individual milk proteins including free amino acids in bovine milk using mid-infrared spectroscopy and their correlations with milk processing characteristics. J. Dairy Sci. 99:3171-3182.

McDermott, A., G. Visentin, S. McParland, D. P. Berry, M. A. Fenelon, and M. De Marchi. 2016b. Effectiveness of mid-infrared spectroscopy to predict the color of bovine milk and the relationship between milk color and traditional milk quality traits. J. Dairy Sci. 99:3267-3273.

McLachlan, C. N. 2001. Beta-casein A1, ischaemic heart disease mortality, and other illnesses. Med. Hypotheses 56:262-272.

McParland, S., and D. P. Berry. 2016. The potential of Fourier transform infrared spectroscopy of milk samples to predict energy intake and efficiency in dairy cows. J. Dairy Sci. 99:4056-4070.

Mero, A. 1999. Leucine supplementation and intensive training. Sports Med. 27:347-358.

Miller, M. J. S., S. A. Witherly, and D. A. Clark. 1990. Casein: A milk protein with diverse biologic consequences. Proc. Soc. Exp. Biol. Med. 195:143-159.

Ng-Kwai-Hang, K. F., J. F. Hayes, J. E. Moxley, and H. G. Monardes. 1987. Variation in milk protein concentrations associated with genetic polymorphism and environmental factors. J. Dairy Sci. 70:563-570.

Ostersen, S., J. Foldager, and J. E. Hermansen. 1997. Associations of stage of lactation, milk protein genotype and body condition at 
calving on protein composition and renneting properties of bovine milk. J. Dairy Res. 64:207-219.

Owens, C. J. W., I. L. Labuschagne, and M. J. Lombard. 2012. The basics of prescribing infant formulas. S. Afr. Fam. Pract. 54:25-30

Sarwar, G., H. G. Botting, T. A. Davis, P. Darling, and P. B. Pencharz. 1998. Free amino acids in milks of human subjects, other primates and non-primates. Br. J. Nutr. 79:129-131.

Shalloo, L., and U. Geary. 2011. Milk payment. Accessed May 11, 2016. http://www.teagasc.ie/dairy/financial/docs/milkpayment. pdf.

Sørensen, M. K., E. Norberg, J. Pedersen, and L. G. Christensen. 2008 Invited review: Crossbreeding in dairy cattle: A Danish perspective. J. Dairy Sci. 91:4116-4128.

Taylor, V. J., D. E. Beever, M. J. Bryant, and D. C. Wathes. 2003. Metabolic profiles and progesterone cycles in first lactation dairy cows. Theriogenology 59:1661-1677.
VanRaden, P. M., and A. H. Sanders. 2003. Economic merit of crossbred and purebred US dairy cattle. J. Dairy Sci. 86:1036-1044.

Wedholm, A., L. B. Larsen, H. Lindmark-Mansson, A. H. Karlsson, and A. Andren. 2006. Association of protein composition on the cheese-making properties of milk from individual dairy cows. J. Dairy Sci. 89:3296-3305.

Willham, R. L., and E. Pollak. 1985. Symposium: Heterosis and crossbreeding. J. Dairy Sci. 68:2411-2417.

Williams, P. 2007. Statistical terms for evaluation of accuracy and precision. Pages 5-1-5-17 in Near Infrared Technology-Getting the Best Out of Light. 5.0 ed. PDK Grain, Nanaimo, BC, Canada.

\section{APPENDIX}

Table A1. Number of records (n), root mean squared error (RMSE), correlation coefficient between true and predicted values in cross-validation $\left(r_{c}\right)$, external validation $\left(r_{v}\right)$, and ratio performance deviation (RPD) tested using the split-sample cross-validation and external validation from McDermott et al. (2016a)

\begin{tabular}{|c|c|c|c|c|c|c|}
\hline \multirow[b]{2}{*}{ Trait } & \multirow[b]{2}{*}{$\mathrm{n}$} & \multicolumn{2}{|c|}{ Cross-validation } & \multicolumn{3}{|c|}{ External validation } \\
\hline & & RMSE & $\mathrm{r}_{\mathrm{c}}$ & RMSE & $\mathrm{r}_{\mathrm{v}}$ & $\mathrm{RPD}$ \\
\hline \multicolumn{7}{|l|}{ Protein, g/L } \\
\hline Total CN & 554 & 4.68 & 0.75 & 4.80 & 0.74 & 1.49 \\
\hline$\alpha_{\mathrm{S} 1}-\mathrm{CN}$ & 557 & 2.16 & 0.70 & 1.26 & 0.66 & 1.35 \\
\hline$\alpha_{\mathrm{S} 2^{-}} \mathrm{CN}$ & 555 & 0.78 & 0.60 & 1.99 & 0.66 & 1.22 \\
\hline$\beta-\mathrm{CN}$ & 555 & 1.92 & 0.69 & 2.37 & 0.67 & 1.33 \\
\hline$\kappa-\mathrm{CN}$ & 556 & 1.25 & 0.67 & 0.81 & 0.56 & 1.33 \\
\hline Total whey & 549 & 1.17 & 0.76 & 1.36 & 0.65 & 1.32 \\
\hline$\alpha-\mathrm{LA}$ & 551 & 0.26 & 0.58 & 0.26 & 0.54 & 1.17 \\
\hline Total $\beta$-LG & 552 & 1.01 & 0.76 & 1.20 & 0.69 & 1.38 \\
\hline$\beta-L G A$ & 557 & 1.14 & 0.43 & 1.16 & 0.39 & 1.09 \\
\hline$\beta-L G$ B & 554 & 1.29 & 0.65 & 1.39 & 0.44 & 1.15 \\
\hline \multicolumn{7}{|l|}{ Free AA } \\
\hline Total free AA & 715 & 16.29 & 0.69 & 17.79 & 0.61 & 1.26 \\
\hline Lys $^{1}$ & 686 & 0.56 & 0.69 & 3.35 & 0.55 & 1.27 \\
\hline $\mathrm{Val}^{1}$ & 625 & 0.57 & 0.60 & 1.93 & 0.59 & 1.14 \\
\hline $\mathrm{Glu}^{1}$ & 714 & 0.41 & 0.68 & 0.46 & 0.59 & 1.2 \\
\hline $\mathrm{Gly}^{1}$ & 699 & 0.41 & 0.75 & 3.50 & 0.75 & 1.38 \\
\hline $\mathrm{Asp}^{1}$ & 595 & 0.55 & 0.58 & 1.66 & 0.44 & 1.15 \\
\hline $\operatorname{Arg}^{1}$ & 612 & 0.38 & 0.66 & 4.35 & 0.26 & 1.25 \\
\hline $\operatorname{Ser}^{1}$ & 591 & 0.48 & 0.51 & 1.22 & 0.42 & 1.07 \\
\hline
\end{tabular}

${ }^{1}$ Traits were $\log$ transformed before analysis. 